\title{
SIKAP MAHASISWA TERHADAP PELAKSANAAN PENDIDIKAN INKLUSI
}

\section{Nirsantono Hasnul}

\begin{abstract}
The aim of this study is describe the implementation of inclusive education at the Department of Special Education, School of Education, State University of Jakarta. The research carried out in 2009 employed survey method. The data was collected using questionnaire by survey including 40 students as the samples out of the population of 70 regular students. The samples consisted of 35 students of 2006 academic year and 5 students of 2005 academic year. The conclusion of the research show that the students have positive attitude towards inclusive education.
\end{abstract}

Key words: attitude, perception, inclusive education

\section{Abstrak}

Penelitian ini bertujuan untuk mengdiskripsikan sikap mahasiswa Jurusan Pendidikan Luar Biasa di Fakultas Ilmu Pendidikan, Universitas Negeri Jakarta. Penelitian yang diselenggarakan tahun 2009 ini menggunakan metode survey dengan menyebar kuesioner kepada 40 mahasiswa sebagai sampel dari populasi 70 mahasiswa. Sampel tersebut terdir atas 35 mahasiswa angkatan 2006 dan 5 mahasiswa angkatan 2005. Hasil peneltian menunjukkan bahwa mahasiswa memiliki sikap positif terhadap pendidikan inklusi.

Kata-kata kunci: sikap, persepsi, pendidikan inklusi

\section{PENDAHULUAN}

Manusia dapat memiliki berbagai sikap terhadap berbagai hal di dalam dunia pendidikan termasuk pada penyelenggaraan pendidikan inklusi di sekolah dasar negeri yang ditunjuk pemerintah tetapi ada juga sekolah dasar swasta yang menyelenggarakan pendidikan sejenis termasuk di sekolah luar biasa. Sikap dapat dikatakan sebagai kesiapan seseorang untuk bertindak dengan cara tertentu terhadap suatu obyek, sikap ini dapat bersifat positif dan negatif, termasuk sikap pada penyelenggaraan sekolah atau pendidikan inklusi di DKI Jakarta, apakah penyelenggaraan sudah sungguh-sungguh seperti yang tercantum dalam teori pendidikan inklusi atau masih menuju penyelenggaraan pendidikan inklusi. Jikahal terakhir masih terjadi dapat dikatakan belum ada kemajuannya.

Individu yang memiliki kesamaan sikap terhadap suatu objyek seperti penyelenggaraan pendidikan inklusi di atas lebih mudah dipersatukan dalam kelompok daripada individu yang sikapnya berbeda-beda. Seseorang dapat bersikap terhadap pelaksanaan pendidikan inklusi jika memiliki kesamaan sikap, semakin besar kesamaan semakin kuat daya tariknya, kesamaan tersebut dikarenakan latar belakang yang sama seperti pendidikan luar biasa, sosial, dan ekonomi.
Pendidikan inklusi merupakan pendidikan yang relatif baru dikembangkan di Indonesia tepatnya mulai dikembangkan pada tahun 2004, pendidikan inklusi yang berkembang sekarang ini belum merupakan pendidikan inklusi yang sesungguhnya, tetapi berupa pendidikan yang menuju pada inklusi karena baru melibatkan anak berkebutuhan khusus dan guru khusus atau Guru Pendidikan Khusus (GPK) yang bergabung pada sekolah dasar penyelenggara pendidikan inklusi.

Pada awalnya, di Indonesia berkembang pendidikan khusus seperti Sekolah Luar Biasa (SLB). Sekolah dasar luar biasa, baik berasrama maupun tidak, yang menyelenggarakan pendidikan untuk anak khusus seperti tunagrahita, tunarungu, tunanetra, tunadaksa, tunalaras atau integrasi dari dua jenis anak luar biasa atau lebih walaupun penyelenggaraan pembelajarannya tidak terintegrasi antara dua atau lebih anak luar biasa, tetapi yang terintegrasi adalah gedung atau tempat bersekolah.

Pendidikan integrasi di Indonesia kurang berjalan karena anak-anak luar biasa yang pertama diintegrasikan tidak bertambah bahkan berkurang. Hal ini disebabkan di antara anak yang diintegrasikan membutuhkan pembelajaran khusus yang sifatnya mendasar untuk menunjang kelancarannya dalam belajar seperti: anak tunanetra, di kelas awal pendidikan dasar atau bahkan pada persiapan 
pendidikannya perlu belajar menulis, membaca Braille, dan orientasi mobilitas; dan anak tunarungu memerlukan belajar bahasa Indonesia, diantaranya oral maupun isyarat karena mereka mengalami masalah pada bidang-bidang tersebut, maka yang sampai sekarang berjalan dengan baik adalah sekolah luar biasa atau sekolah dasar luar biasa.

Mahasiswa Pendidikan Luar Biasa (PLB) terutama mahasiswa regular tahun-tahun terakhir, di samping belajar pendidikan inklusi dari dosendosen jurusan PLB, ada pula yang menjadi guru pendamping khusus di sekolah inklusi sehingga membuat mahasiswa dapat mempelajari yang dimaksud pendidikan inklusi sesungguhnya, bukan terbatas dengan adanya anak berkebutuhan khusus yang belajar bersama dengan anak normal, serta mahasiswa baik yang menjadi Guru Pendidikan Khusus (GPK) di sekolah inklusi maupun yang tidak, akan dapat memberikan sikapnya terhadap pelaksanaan pendidikan atau pembelajaran inklusi.

Pendidikan inklusi sudah berjalan 5 tahun di Indonesia, sudah tentu tidak berjalan di tempat, artinya kemungkinan banyak kemajuan-kemajuan yang telah diperbuat ortopedagogik dan pedagogik.

Berdasarkan latar belakang masalah yang telah diuraikan di atas peneliti tertarik untuk mengetahui pelaksanaan pendidikan inklusi seperti apa yang dilaksanakan atau diterapkan di Indonesia. Masalah penelitian dapat diidentifikasian sebagai berikut: (1) Apakah pelaksanaan pendidikan inklusi di DKI Jakarta sudah mengikuti prinsip-prinsip yang benar? (2) Apakah penyelenggaraan pendidikan inklusi di DKI Jakarta masih menuju pada inklusi? (3) Apakah sikap mahasiswa terhadap penyelenggaraan pendidikan inklusi di DKI Jakarta masih mengikuti prinsip-prinsip pendidikan integrasi? dan (4) Bagaimanakah sikap mahasiswa reguler Jurusan PLB FIP UNJ terhadap penyelenggaraan pendidikan inklusi di DKI Jakarta?

Berdasarkan identifikasi masalah yang telah diuraikan di atas, maka di rumuskan masalah penelitian "Bagaimanakah sikap mahasiswa regular Jurusan PLB tahun terakhir terhadap pelaksanaan pendidikan inklusi di DKI Jakarta?" Adapun asumsi yang dimiliki kami adalah bahwa penyelenggaraan pendidikan inklusi selama ini atau dua tahunan yang lalu masih merupakan menuju penyelenggaraan pendidikan inklusi, artinya belum menyelenggarakan pendidikan inklusi yang sesungguhnya (sesuai dengan teori pendidikan inklusi.

Penelitian ini bermanfaat untuk: (1) mengetahui pemahaman mahasiswa reguler tahun terakhir tentang penyelenggaraan pendidikan inklusi yang benar, dan
(2) memberikan masukan pada Jurusan PLB tentang pengetahuan dan pemahaman mahasiswa terhadap penyelenggaraan pendidikan inklusi.

\section{KAJIAN PUSTAKA}

\section{Pengertian Sikap}

Sikap menurut Morgan dkk (1986) merupakan ekspresi individual yang merupakan evaluasi dari suatu sikap dari objek tertentu. Evaluasi terhadap objek itu diekspresikan menjadi sesuatu yang berhubungan dengan suka, tidak suka, setuju, tidak setuju, positif atau negatif, dan nikmat atau tidak nikmat.

Wortmand dkk (1985) menyatakan bahwa sikap adalah suatu perasaan dekat atau tidak dekat atau pemahaman dengan atau terhadap sekelompok orang tertentu, objek tertentu, ide-ide atau situasi. Sehingga sikap adalah suatu tentang suka atau tidak suka dari perasaan seseorang. Sedangkan menurut Isko dan Scholer (1976) yang dikutip oleh Wortmand dkk (1985) dan Papalia dan Wendkos (1985) sikap adalah suatu konsep yang terdiri dari tiga komponen dasar adalah (1) kognisi atau kepercayaan tentang seseorang, ide-ide, situasi dan sesuatu, (2) reaksi emosi menuju suatu stimulus dan (3) kecenderungan untuk bertindak. Menurut Wirawan (2000) bahwa dalam sikap positif, kecenderungan tindakan adalah mendekati, menyenangi, mengharapkan objek tertentu. Sedangkan dalam sikap negatif terdapat kecenderungan untuk menjauhi, menghindari, membenci, tidak menyukai objek tertentu. Individu yang memiliki kesamaan sikap terhadap objek tertentu lebih mudah dipersatukan dalam kelompok daripada individu yang sikapnya berbeda-beda. Baron, Byrne, dan Kantowiz yang dikutip oleh Irwanto dkk menyatakan bahwa sikap merupakan sekelompok perasaan keyakinan dan kecenderungan berperilaku yang bersifat relatif tahan lama terhadap suatu objek, orang, kelompok, atau isu tertentu.

Pengertian sikap seperti yang dikutip Edwards dalam Dudung (2003) adalah "Attitude is the degree of positive or negative affect associated with some psychological object". Sementara itu, Fishbein dan Ajzen yang dikutip oleh Dudung (2003) menyatakan bahwa sikap seseorang terhadap suatu objek ditentukan oleh keyakinan serta penilaiannya atas objek tersebut atas segala atributnya. Pengertian sikap ini bila seseorang memiliki keyakinan dan berdasar penilaian seseorang terhadap suatu objek, maka terbentuklah sikap seseorang terhadap suatu objek.

Pandangan Fishbein dan Ajzen yang dikutip oleh Dudung (2003) tentang sikap berakar dari teori Thurstone, dia menganggap bahwa afektif 
atau evaluatif merupakan karakteristik utama dari sikap, sehingga afeksi menjadi bagian yang penting dari konsep sikap. Afektif dan evaluatif ditentukan berdasarkan keyakinan seseorang terhadap objek sikap. Jadi sikap seseorang terhadap objek berkaitan dengan keyakinan tentang objek tersebut.

Dari batasan-batasan di atas, terdapat suatu persamaan bahwa sikap adalah sesuatu yang berhubungan dengan suka atau tidak suka, setuju atau tidak terhadap objek tertentu seperti orang, situasi, dan ide. Kesemuanya berdasarkan hasil evaluasi terhadap suatu objek. Bersamaan dengan itu pembahasan yang lebih dalam menurut Insko dan Scholer (1976) dan Papalia dan Windkos (1985) menyatakan sikap terdiri dari kognisi, reaksi emosi dan kecenderungan untuk bertindak. Berarti dapat disimpulkan bahwa sikap adalah suatu kecenderungan untuk bertindak. Hasil dari evaluasi terhadap suatu objek yang merupakan hasil dari kognisi dan reaksi emosional yang dinyatakan dalam bentuk suka atau tidak suka, setuju atau tidak setuju, positif atau negatif dan nikmat atau tidak nikmat. Sedangkan menurut Fishbein yang dikutip Dudung (2003), keyakinan dan kecenderungan bertingkah laku (behavioral intended) bukan bagian dari sikap tetapi merupakan fenomena yang berkaitan dengan sikap. Dengan kata lain, keyakinan dan kecenderungan bertingkah laku merupakan faktor penentu atau konsekuensi dari sikap seseorang. Oleh karena itu, ia memandang sikap sebagai konsep unidimensional yang berkenaan dengan derajat memihak atau menentang terhadap objek psikologi.

Dari pendapat di atas, sikap dikatakan pula sebagai kesiapan atau kecenderungan potensial untuk bereaksi atau bertindak terhadap suatu objek dengan cara-cara tertentu bila seseorang berhadapan dengan suatu stimulus yang mendekati adanya respons. Sesuatu dalam diri seseorang yang merupakan penilaian terhadap objek, biak atau buruk, diinginkan atau dihindari. Berarti sikap itu merupakan hal yang pribadi.

Menurut Winkel, bahwa sikap adalah suatu kecenderungan untuk menerima atau menolak suatu objek berdasarkan penilaian terhadap objek itu sebagai hal yang berguna/berharga (sikap positif) atau tidak berguna (sikap negatif). Pengertian tersebut menjelaskan bahwa sikap sangat mempengaruhi tindakan seseorang.

Menurut Bogardus dalam Mueller, yang dikutip Eddy Swardi K (1996) bahwa sikap adalah suatu kecenderungan bertindak ke arah atau menolak suatu faktor lingkungan. Hal ini senada dengan pendapat Harvey and Smith sebagaimana dikutip
Ahmadi, menyatakan bahwa sikap sebagai kesiapan merespon secara konsisten dalam bentuk positif atau negatif terhadap objek atau situasi. Menurut kedua pendapat di atas bahwa tindakan seseorang sangat dipengaruhi oleh sikapnya terhadap objek sikap yang dihadapinya, bila bersikap positif terhadap suatu objek sikap, akan menimbulkan perilaku yang juga positif dan sebaliknya bila bersikap negatif, seseorang akan bertindak negatif. Sikap positif terhadap suatu objek sikap ditandai oleh adanya kecenderungan tindakan untuk mendekati, menyenangi, dan mengharapkan objek sikap yang dihadapinya. Lebih jauh, seseorang akan siap membantu, memperhatikan, dan berbuat apa saja untuk memperjuangkan objek sikapnya, dan sikap negatif ditandai oleh adanya kecenderungan untuk menjauhi, menghindari, membenci, dan tidak menyukai objek tersebut. Bahkan pada tingkatan tertentu orang tersebut dapat mengecam, mencela, menyerang, atau membinasakan objek sikap yang tidak disukainya.

Allport melihat sikap dari sudut pandang pendekatan sistem. Menurut pendapatnya yang dikutip oleh Mar'at (1982), sikap merupakan suatu sistem yang berkelanjutan dengan komponen kognitif, afektif, dan konatif. Pendapat ini senada dengan pendapat Gagne, bahwa sikap disepakati mengandung tiga segi yang dapat diselidiki secara terpisah atau bersama-sama. Ciri-cirinya adalah: (1) segi kognitif, mengenai gagasan atau proposisi yang menyatakan hubungan antara situasi dan objek sikap; (2) segi afektif, mengenai emosi atau perasaan yang membarengi gagasan; dan (3) segi perilaku, mengenai pradisposisi atau kesiapan untuk bertindak. Katz dan Stotland dalam Travers yang dikutip Dudung (2003) menyatakan bahwa sikap melibatkan tiga komponen yang saling berhubungan, yaitu komponen kognitif, afektif, dan behavior atau konatif.

Menurut pendapat di atas, sikap mengandung tiga komponen yaitu kognitif, afektif dan konatif. Komponen kognitif merupakan konsistensi dari kepercayaan seseorang terhadap objek sikap. Komponen afektif merupakan komponen emosi atau perasaan seseorang terhadap objek yang dicerminkan dengan rasa senang atau tidak senang. Sedangkan komponen konatif berhubungan dengan tindakan atau perilaku seseorang terhadap orang lain yang ditunjukkan melalui sikap sehari-hari.

Perasaan emosi yang ada dalam komponen afektif berhubungan dengan kepercayaan, karena kepercayaan seseorang tentang suatu objek sikap akan mempengaruhi perasaannya terhadap objek tersebut. 
Konatif dikatakan sebagai suatu aktivitas, psikis, yang mengandung usaha aktif yang berhubungan dengan pelaksanaan suatu tujuan. Konatif terdiri dari dorongan, keinginan, hasrat, dan kecenderungan, seseorang yang mengetahui dan mempercayai bahwa suatu objek sikap positif bagi dirinya, maka seseorang cenderung untuk berperilaku positif terhadap objek tersebut dengan cara berusaha mendekati atau memiliki objek sikap tersebut. Berarti sikap timbul dari suatu kepercayaan yang diikuti oleh adanya perasaan. Kedua komponen ini mempengaruhi tindakan seseorang terhadap objek sikap.

Berdasarkan pendapat-pendapat tersebut di atas, dapat dikemukakan bahwa sikap merupakan kecenderungan untuk menerima atau menolak suatu objek berdasarkan penilaian terhadap objek tersebut. Sikap terdiri dari tiga komponen, yakni: (1) kognitif, (2) afektif, dan (3) konatif.

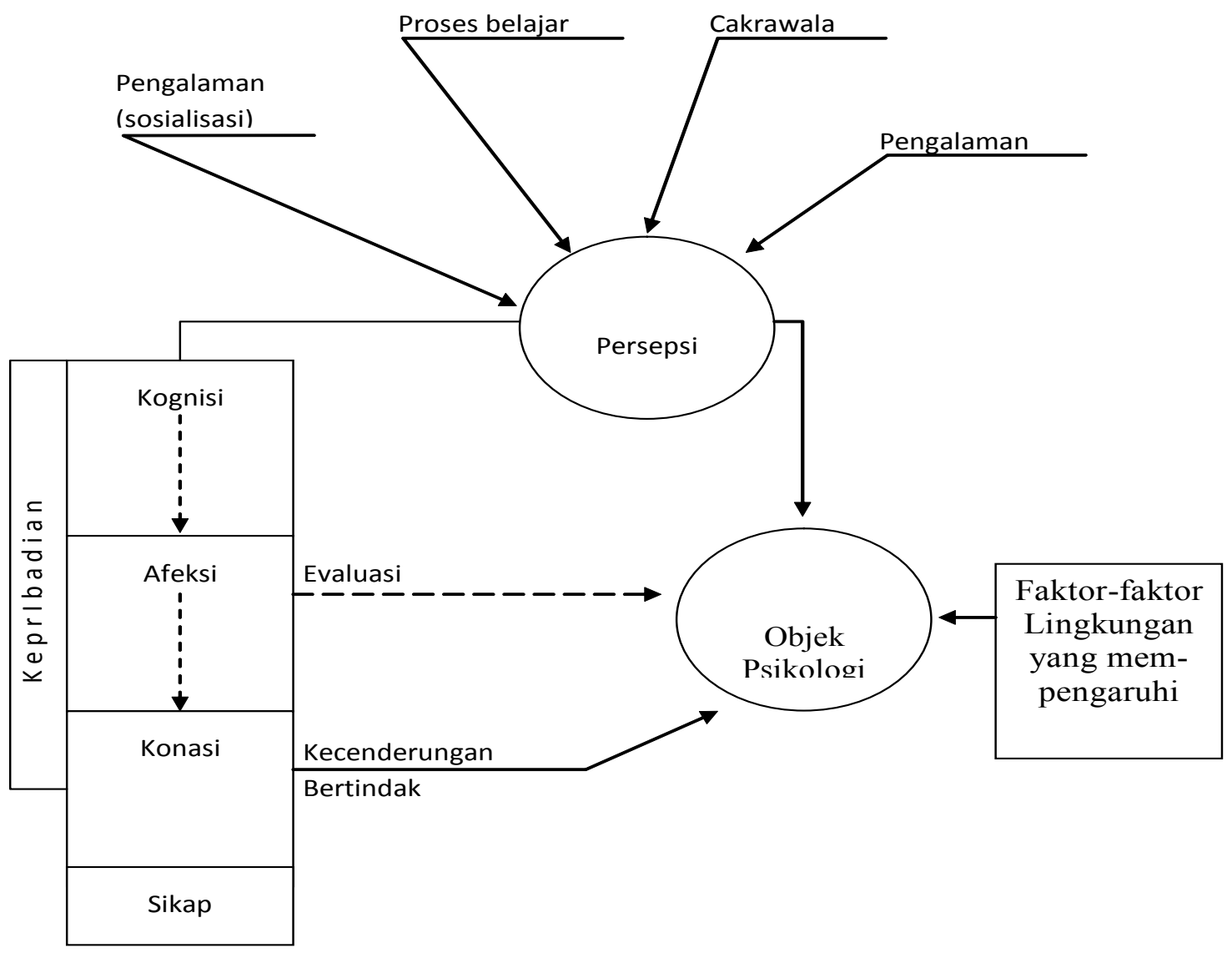

Gambar 1. Bagan Persepsi (Mar'at, 1981)

\section{Pembentukan Sikap}

Sikap sebagai reaksi dalam diri individu memiliki sifat atau ciri-ciri sikap seperti yang dikemukakan Bimo Walgito (2002) bahwa (1) sikap tidak dibawa sejak lahir, (2) sikap selalu berhubungan dengan objek sikap, (3) sikap tidak hanya tertuju pada suatu objek saja, tetapi juga dapat tertuju pada sekumpulan beberapa objek, (4) sikap dapat berlangsung lama atau sebentar, dan (5) sikap mengandung perasaan dan motivasi.

Sikap menurut Papalia dan Wendkos (1985) adalah dipelajari. Sesuai dengan teori belajar bahwa belajar sikap sama seperti belajar yang lain. Terbentuknya atau berubahnya sikap merupakan akibat dari hasil hubungan interpersonal terhadap sesuatu pada suatu periode tertentu. Wortmand dkk
(1985) menegaskan bahwa sikap adalah dipelajari, sikap juga berlangsung untuk waktu yang lama dan sikap mendorong kita untuk bereaksi membantu untuk membentuk langsung tingkah laku terhadap sesuatu.

Dari uraian di atas dapat disimpulkan bahwa sikap terbentuk karena dipelajari atau karena hasil interaksi terhadap sesuatu. Hasil interaksi membentuk suatu kecenderungan untuk bertingkah laku. Sikap itu menjadi sesuatu yang cenderung permanen, nampaknya untuk mengubah suatu sikap tertentu memerlukan waktu yang lama.

\section{Komponen Sikap}

Menurut Breckler, Kate \& Stgotland, Rajeck, Biehm \& Kassin yang dikutip Azwar (1995) bahwa sikap merupakan suatu reaksi terhadap objek 
kombinasi dari afektif, konasi, dan kognisi. Thurstone yang dikutip oleh Muller (1986) bahwa sikap adalah menyukai atau menolak suatu objek psikologis, berarti sikap memiliki objek psikologis.

Menurut Azwar (1995) yang dimaksud kognisi adalah berisi kepercayaan dari seseorang tentang apa yang berlaku atau benar bagi objek sikap. Namun selanjutnya ia menyatakan bahwa kepercayaan itu kurang akurat akibat dari kurang atau tidak adanya informasi yang benar tentang objek yang dihadapi. Kognisi menurut Chaplin (1993) dinyatakan sebagai suatu konsep umum yang berkenaan dengan pengenalan seperti mengamati, menduga dan menilai serta berpikir. Menurut Azwar (1995) bahwa masalah emosional yang subjektif dari seseorang terhadap suatu objek dinamakan dengan komponen afeksi. Pandangan dari Rosenberg dikutip Azwar (1995) menyatakan hal yang sama tentang afektif yaitu suatu perasaan positif atau negatif dari seseorang terhadap suatu objek.

Konasi menurut Azwar (1995) bahwa konasi atau perilaku yang berhubungan dengan kecenderungan dalam diri seseorang untuk berperilaku terhadap objek yang dihadapinya. Hal ini sejalan dengan pendapat Chaplin (1993) bahwa konasi salah satu aspek kepribadian yang ditandai dengan tingkah laku yang bertujuan untuk berbuat.

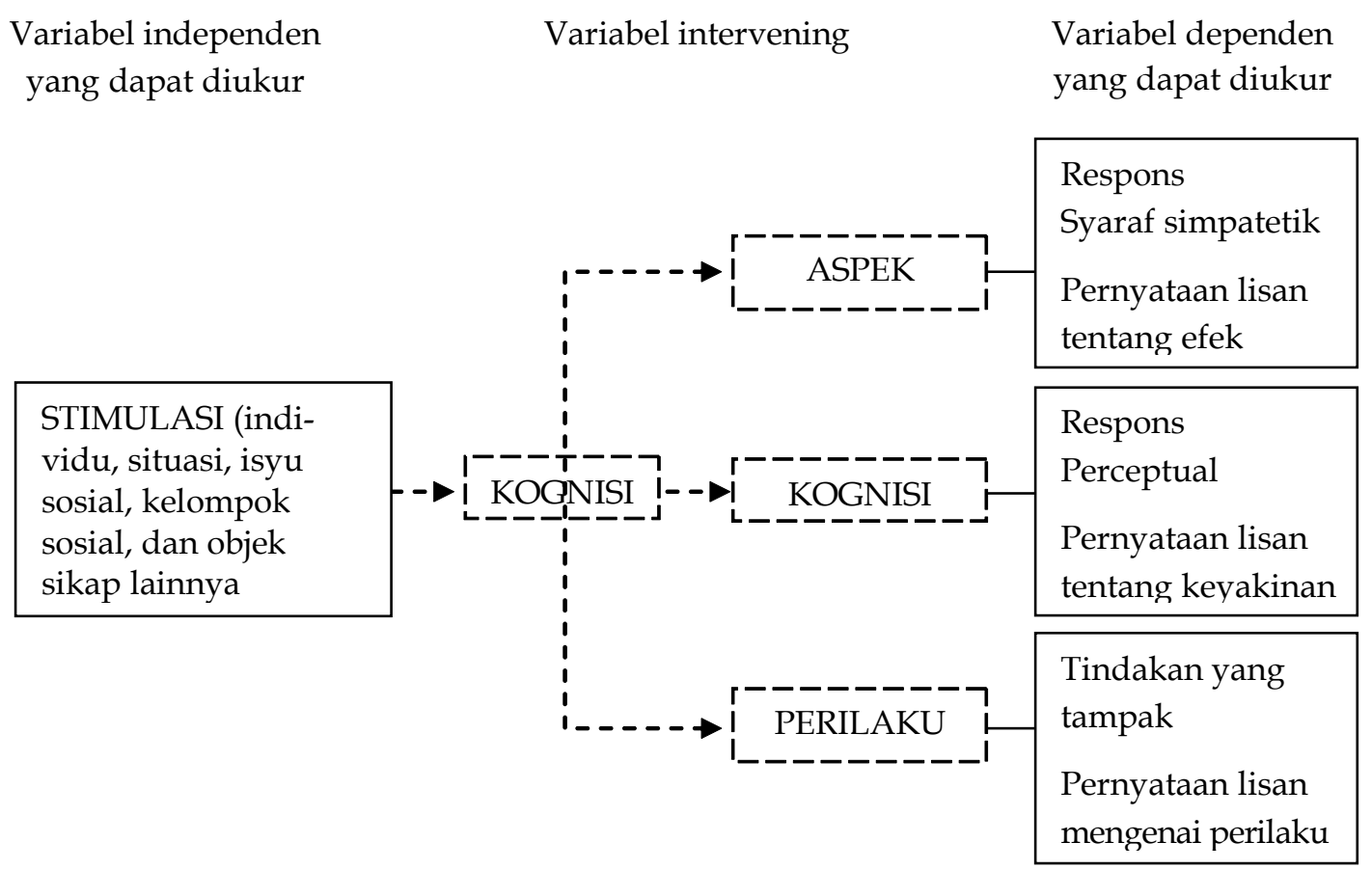

Gambar 2. Konsepsi Skematik Rosenberg \& Hovland mengenai Sikap Diadaptasi dari Fishbein \& Ajzen

(Syaifuddin Azwar, 1997).

\section{Pengertian Pendidikan Inklusi}

Pendidikan inklusi adalah suatu proses yang memusatkan perhatian pada merespon keanekaragaman kebutuhan semua peserta didik melalui partisipasi dalam belajar, budaya dan komunitas, serta mengurangi ekslusif dalam dan dari pendidikan (http:/ Citraedukasi. blogg sport. comI2008/Ollpenelitian-25htm!) Melalui pendidikan inklusi anak berkebutuhan khusus dididik bersamasama dengan anak sebayanya ("normal") untuk merealisasikan secara optimal semua potensi yang dimilikinya.

Menurut Sapon-Shevin yang dikutip oleh Sunardi (1995), inklusi adalah sebagai sistem layanan pendidikan luar biasa yang mempersyaratkan agar semua anak berkebutuhan khusus dilayani di sekolahsekolah terdekat di kelas biasa bersama teman-teman seusianya, dan dengan mudah memperoleh pelayanan pendidikan yang tidak jauh dari tempat tinggalnya, karena keterbatasan fisik dan tenaga yang dimiliki anak berkebutuhan khusus yang mudah lelah. Pendidikan inklusi adalah bentuk layanan dan bantuan yang diberikan kepada anak-anak yang memiliki kebutuhan khusus di sekolah dasar umum (http:/ rumhbljrpsikolog.com/index.phplprinsip.html).

Kelas regular merupakan tempat belajar yang relevan bagi anak berkebutuhan khusus, apapun jenis kelainannya dan bagaimanapun gradasinya. Stau dan Peck dalam Phill Foreman (2001) mengemukakan bahwa pendidikan inklusi adalah penempatan anak 
berkelainan tingkat ringan, sedang, dan berat secara penuh di kelas regular. Pendidikan inklusi adalah mengikutsertakan anak berkebutuhan khusus seperti anak yang memiliki kesulitan melihat atau mendengar, yang tidak dapat berjalan atau lambat dalam berjalan. Namun, secara luas inklusi juga berarti melibatkan seluruh peserta didik tanpa kecuali seperti (1) anak yang menggunakan bahasa yang berbeda dengan bahasa pengantar yang digunakan di dalam kelas, (2) anak yang beresiko putus sekolah karena sakit, kelaparan atau tidak berprestasi dengan baik, (3) anak yang berasal dari golongan agama atau kasta yang berbeda, (4) anak yang sedang hamil, (5) anak yang terinfeksi HIV/ AIDS, dan (6) orang yang berusia sekolah tetapi tidak sekolah karena masalah ekonomi (Direk PLB, 2004).

Sopan-Shepin yang dikutip oleh Arum (1995:100) mendefinisikan inklusi sebagai sistem layanan pendidikan luar biasa yang mempersyaratkan agar semua anak luar biasa dilayani di sekolah-sekolah terdekat di kelas bersama teman-teman sebayanya.

SedangkanStainback danStainback yang dikutip oleh Arum (2005:100) memberikan pendapat tentang sekolah inklusi bahwa yang dimaksud dengan sekolah yang inklusi adalah sekolah yang menampung semua murid di kelas yang sama. Sekolah ini menyediakan program pendidikan yang layak, menantang, tetapi sesuai dengan kemampuan dan kebutuhan setiap murid maupun bantuan dan dukungan yang dapat diberikan oleh para guru agar anak-anak berhasil. Lebih dari itu yang disebut sekolah inklusi adalah merupakan tempat bagi setiap anak dan tidak ada lagi istilah PLB, semua anak dapat diterima menjadi bagian dari kelas tersebut, dan saling membantu dengan guru dan teman sebaya maupun anggota masyarakat lain agar kebutuhan individualnya terpenuhi.

Pendidikan inklusi tidak hanya menyangkut anak berkebutuhan khusus yang disekolahkan bersama anak normal di sekolah dasar saja, tetapi pada esensinya menciptakan sistem yang dapat mengakomodasi semua jenis anak dan melibatkan berbagai pihak dalam penyelenggaraan pendidikan inklusi tersebut.

Melalui pendidikan inklusi, anak berkebutuhan khusus dididik bersama-sama anak lainnya ('normal') untuk mengoptimalkan potensi yang dimilikinya. Hal ini dilandasi oleh kenyataan bahwa di dalam masyarakat terdapat anak 'normal' dan anak berkebutuhan khusus yang tidak dapat dipisahkan sebagai suatu komunitas. Oleh karena itu, anak berkebutuhan khusus perlu diberi kesempatan dan peluang yang sama dengan anak 'normal' untuk mendapatkan pelayanan pendidikan di sekolah terdekat.

Pendidikan inklusi menurut Direktorat PLB, Dirjen Dikdasmen (2004) sebagai wadah yang ideal, pendidikan inklusi memiliki karakteristik makna yaitu (1) proses yang berjalan terus dalam usahanya menemukan cara-cara merespon keragaman individu anak; (2) mempedulikan cara-cara untuk meruntuhkan hambatan-hambatan anak dalam belajar; (3) membawa makna bahwa anak kecil yang hadir (di sekolah), berpartisipasi dan mendapatkan hasil belajar yang bermakna dalam hidupnya; dan (4) diutamakan bagi anak-anak yang tergolong marginal, ekslusif, dan membutuhkan layanan pendidikan khusus dalam belajar.

Hal ini dapat memberikan pengaruh yang positif bagi dunia pendidikan. Dengan adanya kemudahan akses bagi semua peserta didik untuk mendapatkan pendidikan di sekolah-sekolah terdekat. Peserta didik akan mendapatkan pelayanan yang akan disesuaikan dengan karakteristik masing-masing individu. Bersama dengan anak-anak lainnya, anakanak berkebutuhan khusus dapat mengembangkan potensinya secara optimal.

Banyak manfaat atau kelebihan pendidikan inklusi diantaranya menurut Staub dan Peck seperti yang dikutip Arum (2005:144-145), mengkaji banyak penelitian yang berkaitan dengan manfaat atau kelebihan pendidikan inklusi, diantaranya: berkurangnya rasa takut akan perbedaan individual dan semakin besarnya rasa percaya dan peduli pada anak luar biasa.

Hilangnya rasa takut pada orang yang menunjukkan kelainan merupakan akibat seringnya berinteraksi dengan anak luar biasa di kelas. Orangtua juga melaporkan bahwa tidak hanya anak-anak yang 'normal' yang kemudian peduli, menghargai, dan tidak takut pada penyandang cacat, anak-anak normal juga sendiri semakin sadar akan perbedaan individu anak.

(1) Pertumbuhan kognisi sosial. Murray - Seegert mengadakan penelitian ethnographic di sebuah sekolah inklusi. Hasilnya menunjukkan bahwa anak-anak 'normal' menjadi semakin toleran pada orang lain, setelah mereka memahami kebutuhan individu teman sebayanya yang cacat. Mereka juga semakin merasa positif tentang dirinya sendiri setelah lama membantu teman sebayanya yang cacat berat.

(2) Peningkatan konsep diri (self concept). Banyak anak 'normal' yang mengakui peningkatan self-esteem sebagai akibat pergaulannya dengan anak luar 
biasa. Hasil penelitian menunjukkan bahwa muridmurid menganggap bahwa pergaulan mereka dengan anak luar biasa telah meningkatkan status mereka di kelas dan sekolah.

(3) Pertumbuhan prinsip-prinsip pribadi. Banyak anak 'normal' yang mengalami perkembangan dalam komitmen mereka pada moral pribadi dan prinsip-prinsip etika sebagai akibat hubungan mereka dengan anak luar biasa. Orangtua juga melaporkan bahwa anaknya menjadi tidak terlalu curiga terhadap orang yang berbeda darinya.

(4) Persahabatan yang erat dan penuh perhatian.dalam banyak hal, hubungan yang tumbuh antara anak 'normal' dengan anak luar biasa yang bersangkutan untuk memantau terjadinya perubahan ke arah terwujudnya sistem pendidikan inklusi yang lebih baik. Selain pembinaan sekolah luar biasa (SLB) yang merupakan setting pendidikan segregasi, Direktorat PLB menangkap isu penting tentang pendidikan inklusi atau terpadu untuk mengangkat hak anak atas pendidikan sekaligus mewujudkan misi perluasan kesempatan memperoleh pendidikan.

Membangun atmosfer inklusi menurut Lang dan Berberich seperti yang dikutip oleh Siti Nuraini P dkk adalah dari suatu rentangan yang luas dari hubungan antara masyarakat dan berbagai pertimbangan yang semuanya dipengaruhi dari berbagai pengalaman, kepercayaan, dan sikap, yang dapat digambarkan sebagai berikut :
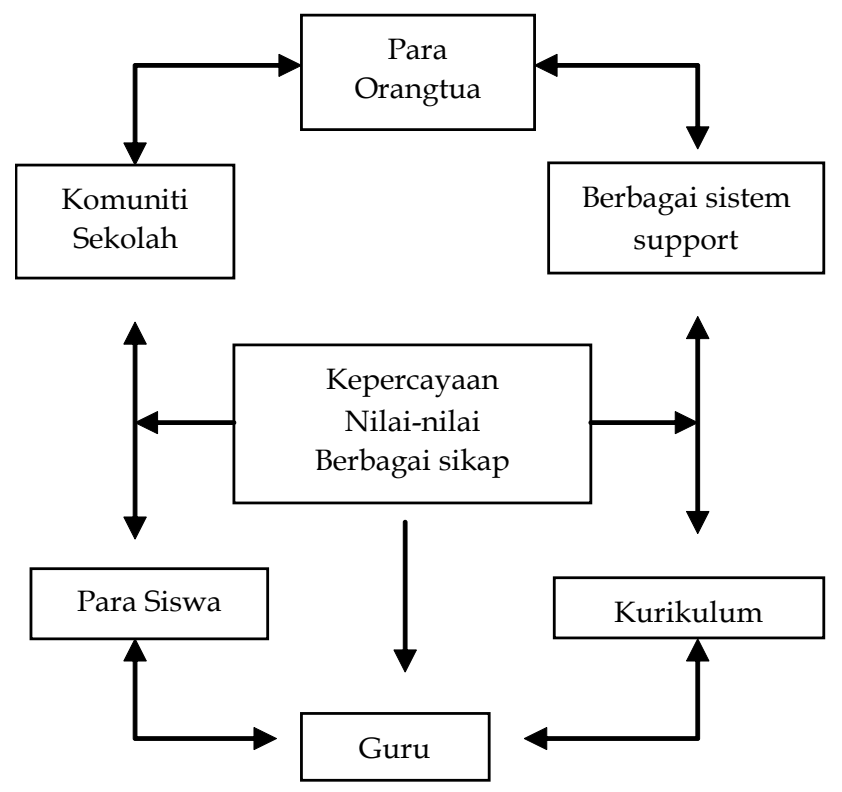

Gambar 3. Atmosfer Pendidikan Inklusi (Nuraini, 2003:15-16)

\section{Penyelenggaraan Pembelajaran pada Pendidikan Inklusi}

Pelaksanaan kegiatan belajar mengajar di kelas inklusi secara umum sama dengan pelaksanaan kegiatan belajar-mengajar di kelas reguler. Namun demikian, karena di dalam kelas inklusi di samping terdapat anak 'normal' juga terdapat anak luar biasa yang mengalami kelainan/ penyimpangan (baik fisik, intelektual, sosial, emosional, dan/atau sensoris neurologis) dibanding dengan anak 'normal', maka dalam kegiatan belajar-mengajar guru yang mengajar di kelas inklusi di samping menerapkan prinsipprinsip umum juga harus mengimplementasikan prinsip-prinsip khusus penyelenggaraan pendidikan inklusi sesuai dengan kelainan anak karena para siswanya lebih heterogen.

Sapon-Shevin yang dikutip oleh Sunardi mengemukakan lima profil pembelajaran di sekolah inklusi, yaitu:

1. Pendidikan inklusi berarti mencipta-kan dan menjaga komunitas kelas yang hangat, menerima keanekaragaman, dan menghargai perbedaan. Guru mempunyai tanggung jawab menciptakan suasana kelas yang menampung semua anak secara penuh dengan menekankan suasana dan perilaku sosial yang menghargai perbedaan yang menyangkut kemampuan, kondisi fisik, sosial-ekonomi, suku, agama, dan sebagainya. Pendidikan inklusi berarti penerapan kurikulum yang multilevel dan multimodalitas.

2. Mengajar kelas yang heterogen memerlukan perubahan pelaksanaan kurikulum secara mendasar. Pembelajaran di kelas inklusi akan bergeser dari pendekatan pembelajaran kompetitif yang kaku, mengacu materi tertentu, ke pendekatan pembelajaran kooperatif yang melibatkan kerjasama antarsiswa, dan bahan belajar tematik.

3. Pendidikan inklusi berarti menyiapkan dan mendorong guru untuk mengajar secara interaktif. Perubahan dalam kurikulum berkaitan erat dengan perubahan metode pembelajaran. Model kelas tradisional di mana seorang guru secara sendirian berjuang untuk dapat memenuhi kebutuhan semua anak di kelas harus bergeser dengan model antarsiswa saling bekerjasama, saling mengajar dan belajar, dan secara aktif saling berpartisipasi dan bertanggung jawab terhadap pendidikannya sendiri dan pendidikan teman-temannya. Semua anak berada di satu kelas bukan untuk berkompetisi melainkan untuk saling belajar dan mengajar dengan yang lain.

4. Pendidikan inklusi berarti penyediaan dorongan bagi guru dan kelasnya secara terus menerus dan penghapusan hambatan yang berkaitan dengan isolasi profesi. Meskipun guru selalu berinteraksi dengan orang lain, pekerjaan mengajar dapat 
menjadi profesi yang terisolasi. Aspek terpenting dari pendidikan inklusi adalah pengejaran dengan tim, kolaborasi dan konsultasi, serta berbagai cara mengukur keterampilan, pengetahuan, dan bantuan individu yang bertugas mendidik sekelompok anak. Oleh karena itu, untuk dapat bekerjasama dengan orang lain secara baik memerlukan pelatihan dan dorongan secara terusmenerus.

5. Pendidikan inklusi berarti melibatkan orangtua secara bermakna dalam proses perencanaan. Keberhasilan pendidikan inklusi sangat bergantung kepada partisipasi aktif dari orangtua pada pendidikan anaknya, misalnya keterlibatan mereka dalam penyusunan Program Pengajaran Individual (PPI) dan bantuan dalam belajar di rumah (Direktorat PLB, Dirjen Dikdasmen, 2004).

\section{Kesesuaian dan Kesenjangan Teori dengan} Kebijakan

Model program pendidikan inklusi dapat dilakukan dengan pengelompokan sebagai berikut: (a) Model mainstreaming/terpadu penuh: ABK bersama siswa reguler belajar sepanjang hari di kelas reguler dengan menggunakan kurikulum dan metode yang sama (tanpa modifikasi); (b) Model inklusi penuh : ABK bersama siswa reguler berada sepanjang hari di kelas reguler dengan menggunakan kurikulum yang dapat dimodifikasi sesuai dengan kebutuhan ABK; (c) Model inklusi/integrasi sebagian: ABK berada di sekolah reguler (di kelas reguler) dalam waktu tertentu (bisa dengan bantuan ataupun tidak dibantu oleh GPK), dan bisa ditarik atau belajar di ruang sumber dengan GPK; dan (d) Model kelas khusus: ABK berada di kelompok khusus, kelas khusus dengan guru khusus di sekolah reguler.

Model inklusi/integrasi mana pun yang ingin diterapkan di Indonesia, tergantung dari: (a) kesiapan sekolah, (b) ketersediaan dan kesiapan tenaga, kependidikan, (c) jenis dan tingkat ABK yang akan dilayani, dan (d) sarana dan prasarana yang tersedia.

Model di atas mengacu pada model pendidikan integrasi, tetapi kalau pendidikan inklusi hanya menyediakan satu jenis layanan pendidikan yaitu anak berkebutuhan khusus mendapat pendidikan bersama anak seusianya yang dididik oleh guru kelas.

\section{Pendidikan Segregasi}

Menurut Arum (2005:106), dalam sistem pendidikan yang segregatif, siswa dikelompokkan dalam dua kategori, yaitu normal dan berkelainan, sebagai konsekuensi dari pandangan yang dikotomis semacam itu maka siswa yang normal dimasukkan ke sekolah reguler sedangkan yang berkelainan dimasukkan ke sekolah khusus atau sekolah luar biasa. Menurut Somad dan Herawati, sistem segregasi adalah sistem penyelenggaraan pendidikan yang dilaksanakan secara khusus dan terpisah dari penyelenggaraan pendidikan dari anak dengar atau anak normal. Dengan kata lain, anak tunarungu diberikan layanan pendidikan pada lembaga pendidikan khusus untuk anak luar biasa seperti sekolah luar biasa untuk anak tunarungu (SLB/B).

Dari pengertian di atas, pendidikan segregatif dapat dikatakan sebagai suatu sistem pendidikan yang di dalamnya terdapat unsur pemisahan antara pendidikan bagi siswa normal dengan siswa berkelainan termasuk siswa tunarungu. Akibat pengkategorian tersebut maka muncullah berbagai jenis SLB. Di Indonesia sendiri bisa kita temui berbagai macam jenis SLB, namun jumlah sekolah luar biasa yang disediakan oleh pemerintah masih belum memadai, maka pihak swasta mendirikan sekolah luar biasa swasta untuk membantu memenuhi kebutuhan dunia pendidikan akan sekolah bagi anak-anak berkebutuhan khusus.

Arum (2005:101) mengemukakan bahwa perkembangan pendidikan luar biasa di Indonesia dimulai pada masa sebelum merdeka yaitu pertama kali pada tahun 1901 dengan dibukanya satu lembaga untuk penyandang tunanetra. Kemudian pada tahun 1927 dibuka sekolah bagi anak tunagrahita di kota Bandung. Pada saat yang hampir sama sebuah sekolah khusus bagi anak tunarungu wicara putri didirikan di kota Wonosobo, Jawa Tengah.

Dari uraian di atas, diketahui bahwa sekolah luar biasa sudah ada sejak sebelum Indonesia merdeka. Ini menandakan bahwa pendidikan segregatif sudah berkembang sejak dahulu. Masyarakat Indonesia pada era itu sudah menyadari betapa pentingnya pendidikan bagi anak-anak berkebutuhan khusus. Namun, sayangnya dewasa ini pendidikan luar biasa di Indonesia belum berkembang dengan baik dan belum mendapat perhatian yang memadai dari pemerintah. Bahkan sering dijumpai anak-anak luar biasa yang tidak bersekolah karena kurangnya perhatian dari pemerintah dan masyarakat. Biaya pendidikan yang tinggi juga menjadi penghalang bagi keluarga yang tidak mampu untuk mendapatkan pendidikan bagi anak-anak mereka yang memiliki kebutuhan khusus.

Sistem pendidikan segregatif ini tentunya memiliki keunggulan antara lain anak-anak berkebutuhan khusus termasuk tunarungu berada pada suatu komunitas di mana mereka bisa mendapatkan 
pendidikan yang sesuai dengan kebutuhan mereka. Kurikulum dapat disesuaikan dengan jenis ketunaan sehingga lebih tepat sasaran. Anak berkebutuhan khusus juga dapat lebih merasa nyaman karena berada dalam satu komunitas dimana mereka merasa sama-sama berkebutuhan khusus. Guru dan pihak sekolah akan lebih fokus dalam memberikan pelayanan kepada pada ABK karena homogenitas yang ada membuat pelayanan lebih tepat sasaran. Guru-guru juga akan disiapkan sesuai dengan skill atau kemampuan mengajar yang dimiliki. Dengan disiapkannya guru-guru khusus yang memiliki kemampuan mengajar sesuai dengan kebutuhan anak, maka proses pembelajaran akan berjalan dengan baik dan mendapatkan hasil yang sesuai dengan tujuan pembelajaran.

\section{Pendidikan Integrasi}

Pendidikan Integrasi dapat diartikan pula sebagai pendidikan terpadu. Dalam sistem pendidikan Integrasi, anak-anak berkebutuhan khusus termasuk anak tunarungu ditempatkan di kelas biasa atau regular bersama dengan teman sekelasnya. ABK belajar bersama anak normal dengan pelayanan pendidikan yang hampir sama mengikuti anak normal lainnya.

Sistem integrasi sering disebut sistem terpadu karena sistem pendidikan ini membawa anak tunarungu kepada suasana keterpaduan dengan anak dengar baik keterpaduan bersifat menyeluruh atau bersifat sosialisasi. Untuk membantu anak tunarungu yang mengalami kesulitan dalam proses pembelajaran, disediakan guru pembimbing khusus atau GPK yang berfungsi sebagai konsultan bagi guru kelas, kepala sekolah, ataupun anak tunarungu itu sendiri.

Menurut Arum (2005:85), integrasi adalah bentuk pendidikan terpadu di Indonesia yang tidak identik dengan konsep mainstreaming atau inklusi di negara barat.

Dapat ditarik kesimpulan bahwa pendidikan integrasi adalah penempatan siswa berkebutuhan khusus termasuk siswa tunarungu di kelas biasa bersama dengan siswa normal lainnya, namun sistem pendidikan ini berbeda dengan pendidikan inklusi dan mainstreaming di negara barat sehingga perlu disempurnakan lagi. Pendidikan integrasi masih dianggap belum sesuai bagi siswa berkebutuhan khusus karena masih mendapatkan layanan pendidikan yang sama dengan siswa normal lainnya. Idealnya siswa berkebutuhan harus mendapatkan layanan pendidikan yang sesuai dengan kebutuhan individu dan kecacatan yang dimilikinya. Oleh sebab itu dibutuhkan sarana dan fasilitas serta tenaga pendidik yang khusus bagi yang mengalami ketunaan. Penyempurnaan dari pendidikan integrasi di Indonesia dikenal dengan pendidikan inklusi.

Pendidikan integrasi memiliki beberapa keunggulan dan kelemahan. Keunggulan sistem pendidikan ini diantaranya siswa tunarungu dan siswa luar biasa lainnya merasa mendapatkan kesamaan hak dengan anak normal terutama dalam memperoleh pendidikan formal. Pada anak-anak luar biasa dengan ketunaan tertentu seperti tunarungu dan tunanetra mempunyai kesempatan untuk melanjutkan pendidikan ke jenjang yang lebih tinggi. Kesamaan hak dan kesempatan melanjutkan pendidikan ke jenjang yang lebih tinggi memang perlu bagi siswa berkebutuhan khusus. Hal ini menjadi salah satu keunggulan bagi pendidikan integrasi. Dengan adanya kesamaan hak dan kesempatan melanjutkan pendidikan, maka siswa dengan kebutuhan khusus dapat lebih mengembangkan diri dan mendapatkan pendidikan yang lebih tinggi.

Kelemahan pendidikan integrasi antara lain siswa berkebutuhan khusus harus belajar dengan keras, karena harus menerima materi pelajaran melalui cara yang biasa digunakan pada anak normal. Beban kerja guru juga bertambah karena harus memperhatikan siswa luar biasa yang berada di kelasnya terutama dalam hal penggunaan metode penyampaian materi pelajaran. Siswa berkebutuhan khusus mempunyai keterbatasan sesuai dengan jenis ketunaan yang mereka alami. Maka mereka akan sulit jika harus mengikuti materi sesuai dengan standar materi pelajaran sekolah umum. Cara pembelajaran yang biasa dilakukan bagi siswa yang normal juga belum tentu tepat dan cocok bagi siswa berkebutuhan khusus. Walau bagaimanapun, siswa berkebutuhan khusus membutuhkan pelayanan pendidikan khusus yang sesuai dengan kebutuhan mereka.

Beban kerja guru tentu akan bertambah karena siswa berkebutuhan khusus membutuhkan perhatian dan pelayanan yang berbeda dengan siswa normal lainnya. Apalagi, tidak semua guru kelas memiliki pengetahuan dan kemampuan dalam menangani anak berkebutuhan khusus. Karena kelemahan inilah maka pendidikan integrasi perlu disempurnakan dengan pendidikan inklusi.

\section{Pendidikan Inklusi}

Pendidikan inklusi adalah pendidikan yang mempersatukan layanan pendidikan luar biasa dengan pendidikan regular dalam satu sistem pendidikan atau penempatan semua anak luar biasa di sekolah biasa. Dengan pendidikan inklusi semua anak luar biasa dapat bersekolah di sekolah terdekat dan di sekolah 
yang menampung semua anak.

Dapat dikatakan bahwa pendidikan inklusi adalah penggabungan dari sistem pendidikan segregasi dan integrasi. Dalam pendidikan inklusi, anakanak luar biasa termasuk anak tunarungu dapat bersekolah di sekolah umum bersama anak normal lainnya dengan mendapatkan pelayanan khusus sesuai dengan kebutuhannya. Dalam pendidikan inklusi siswa berkebutuhan khusus akan bersekolah di sekolah umum dengan disediakan fasilitas dan sarana yang memadai bagi siswa berkebutuhan khusus tersebut. Kurikulum akan disesuaikan sesuai dengan kebutuhan individu setiap anak. Di sekolah inklusi, siswa berkebutuhan akan berinteraksi dengan berbagai individu, baik guru kelas, guru pembantu khusus, kepala sekolah, teman-teman yang normal, teman-teman sesama siswa berkebutuhan khusus, dan warga sekolah lainnya.

Sistem pendidikan inklusi ini dianggap fleksibel dan cocok bagi anak luar biasa termasuk anak tunarungu. Di Indonesia sendiri pendidikan inklusi mulai diprogramkan pada tahun 2001. Namun, hingga saat ini sistem pendidikan inklusi belum sepenuhnya dapat dilaksanakan dengan baik di sekolah-sekolah regular. Bahkan sangat jarang ditemukan sekolah yang menerapkan sistem pendidikan ini dengan baik.

Untuk dapat diterapkan dengan baik di sekolah-sekolah regular, pemerintah perlu membuat agenda sosialisasi yang lebih baik dan tepat sasaran. Sosialisasi sistem pendidikan inklusi sangat penting guna terwujudnya pendidikan inklusi yang sesuai di sekolah-sekolah umum.

Keunggulan sistem pendidikan inklusi antara lain sistem pendidikan ini merupakan sistem pendidikan yang sangat tepat dan sesuai bagi siswa berkebutuhan khusus. Penerapan sistem pendidikan yang disesuaikan dengan kebutuhan siswa dan pengadaan sarana dan fasilitas serta tenaga pendidik khusus membuat sistem pendidikan ini begitu sesuai bagi mereka yang memiliki keterbatasan. Selain itu, siswa berkebutuhan khusus juga dapat bersosialisasi dengan siswa normal lainnya sehingga tidak ada batasan atau rasa minder bagi siswa berkebutuhan. Hal ini penting bagi perkembangan psikologis mereka sehingga dikemudian hari jika mereka terjun dalam masyarakat umum, mereka sudah terbiasa dan tidak canggung lagi dalam pergaulan sehari-hari.

Kelemahan sistem pendidikan inklusi antara lain kurangnya sosialisasi dari pemerintah sehingga masyarakat kurang mengenal apaitu sistem pendidikan inklusi. Sekolah-sekolah umum juga masih jarang yang menerapkan sistem pendidikan ini sehingga tidak banyak siswa berkebutuhan khusus yang bisa mendapatkan layanan pendidikan inklusi.

\section{METODOLOGI PENELITIAN}

Tujuan penelitian adalah untuk mendapatkan data empiris tentang penyelenggaraan pendidikan inklusi di DKI Jakarta. Adapun manfaat hasil penelitian adalah: (1) Menggambarkan penyelenggaraan pendidikan inkluasi di DKI Jakarta, (2) Memberikan masukan pada dosen-dosen jurusan PLB FIP Universitas Negeri Jakarta, dan (3) sebagai masukan bagi direktur PLB.

Penelitianini dilaksanakan diJurusanPendidikan Luar Biasa (PLB) Fakultas Ilmu Pendidikan (FIP) Universitas Negeri Jakarta (UNJ). Waktu penelitian ini dilaksanakan dalam 5 bulan dari tanggal 27 Maret 2009 sampai 28 Oktober 2009. Tahap penelitian yaitu (1) penyusunan proposal, (2) memperbaiki proposal, (3) penyusunan instrumen penelitian, (4) uji coba instrumen, (5) pengambilan data, (6) analisis data, (7) penyusunan laporan hasil penelitian, (8) seminar hasil penelitian, (9) perbaikan laporan penelitian, dan(10) penyerahan laporan hasil penelitian.

Metode penelitian yang digunakan dalam penelitian ini (sesuai dengan perumusan masalah di atas) adalah metode survei dengan pendekatan deskriptif. Teknik pengumpulan data menggunakan skala sikap tentang sikap mahasiswa Jurusan PLB tahun terakhir terhadap pelaksanaan pendidikan inklusi di DKI Jakarta, analisis data yang akan digunakan adalah statistik deskriptif, cara penafsiran hasil penelitian menggunakan rata-rata ideal, dan untuk kesimpulan disesuaikan dengan hasil penafsiran tersebut.

Populasi penelitian ini adalah mahasiswa reguler tahun terakhir yaitu angkatan 2005 dan angkatan 2006 Jurusan PLB FIP UNJ. Teknik pengambilan sampel menggunakan strategi field random sampling, dari mahasiswa Jurusan PLB FIP UNJ angkatan 2006 adalah 20 orang, dan dari angkatan 2005 sebanyak 15 orang, total sampel 35 mahasiswa.

Pengumpulan data dalam penelitian ini menggunakan satu instrumen yaitu angket sikap mahasiswa PLB FIP UNJ reguler tahun terakhir terhadap penyelenggaraan pendidikan inklusi di DKI Jakarta.

Instrumen penelitian ini mengacu pada skala likert, jawaban angket ini adalah SS = sangat setuju, $S$ = setuju, $\mathrm{R}=$ ragu-ragu, TS = tidak setuju, dan STS = sangat tidak setuju. Definisi Konseptual

Sikap suatu perasaan dekat atau tidak dekat, pemahaman terhadap se kelompok orang tertentu, obyek tertentu ide-ide atau situasi, terdiri dari tiga 
komponen (1) kognisi adalah gagasan atau proporsi yang menyatakan hubungan antara situasi dan objek, yang merupakan konsistensi dari kepercayaan seseorang terhadap objek sikap, (2) afektif adalah tentang emosi/program seseorang membarengi gagasan, dan (3) konasi adalah perilaku mengenai pradisposisi/kesiapan untuk bertindak. Sikap dapat positif atau sebaliknya. Definisi operasional sikap mahasiswa terhadap penyelenggaraan pendidikan inklusi di daerah DKI Jakarta adalah skor yang diperoleh dari jawaban instrumen penelitian yang terdiri (1) kognisi, (2) afeksi, dan (3) konasi.

Analisis data menggunakan statistik deskriptif dan rata-rata ideal.

\section{HASIL DAN PEMBAHASAN}

\section{Hasil Penelitian}

Pada penelitian ini skor sikap mahasiswa reguler tahun terakhir jurusan PLB-FIP UNJ diperoleh melalui skala sikap yang data mentahnya berskala 0-250, dan skor setelah dianalisis menjadi skor 0-100, data tersebut diperoleh dari mahasiswa angkatan 1995 dan 1996.

Data yang terkumpul dianalisis dengan statistik deskriptif maka diperoleh rata-rata 81,85 dari hasil perhitungan diperoleh pula simpangan baku (S) 4,38 dan variansi sebesar $\left(S^{2}\right)$ 19,16, serta diperoleh pula ukuran letak yaitu modus sebesar 79,09 dan median 80,96, kemudian data terkecil 72 data terbesar 90 .

Tabel 1. Ukuran Gejala Pusat dan Ukuran Letak

\begin{tabular}{|l|c|}
\hline Gejala Pusat dan Letak & Ukurannya \\
\hline Skor tertinggi & 90 \\
\hline Skor terendah & 72 \\
\hline Rata-rata & 81,85 \\
\hline Simpangan baku (S) & 4,38 \\
\hline Variansi & 19,16 \\
\hline Modus & 79,09 \\
\hline Median & 80,96 \\
\hline
\end{tabular}

Berikut ini skor sikap mahasiswa reguler tahun terakhir jurusan PLB-FIP UNJ terhadap pelaksanaan pendidikan inklusi di DKI Jakarta disusun ke dalam daftar distribusi frekuensi absolut dan relatif, juga disusun dalam daftar distribusi frekuensi kumulatif dan kumulatif proporsional.

Daftar distribusi frekuensi ini digunakan supaya datanya dapat dibaca dengan mudah, termasuk untuk melihat frekuensi tertinggi dan terendah.
Tabel 2. Daftar Distribusi Frekuensi Absolut dan Relatif

\begin{tabular}{|c|c|c|c|}
\hline Kelas & $\mathrm{F}$ & Tanda Kelas & fr $(\%)$ \\
\hline $72-74$ & 1 & 72,5 & 2,50 \\
\hline $75-77$ & 4 & 75,5 & 10,00 \\
\hline $78-80$ & 13 & 78,5 & 32,50 \\
\hline $81-83$ & 5 & 81,5 & 12,50 \\
\hline $84-86$ & 10 & 84,5 & 25,00 \\
\hline $87-89$ & 6 & 87,5 & 15,00 \\
\hline $90-92$ & 1 & 90,5 & 2,50 \\
\hline Jumlah & 40 & & \\
\hline
\end{tabular}

Daftar distribusi digunakan untuk mengelompokkan data, dari kelas interval tersebut frekuensi terendah adalah satu dan frekuensi tertinggi sebesar 13, maka skor terbanyak terletak pada rentangan 78-80, kemudian terbanyak kedua pada rentangan interval $84-86$, dan yang paling sedikit pada rentangan $72-74$ dan 90-92.

Tabel 3. Daftar Distribusi Frekuensi Kumulatif

\begin{tabular}{|c|c|c|c|c|c|}
\hline Nilai & $\begin{array}{c}\mathrm{f} \\
\text { kum }\end{array}$ & $\begin{array}{c}\mathrm{f} \text { kum } \\
(\%)\end{array}$ & Nilai & $\begin{array}{c}\mathrm{f} \\
\text { kum }\end{array}$ & $\begin{array}{c}\mathrm{f} \text { kum } \\
(\%)\end{array}$ \\
\hline$<72$ & 0 & 0,00 & $\geq 72$ & 40 & 100,00 \\
\hline$<75$ & 1 & 2,50 & $\geq 75$ & 39 & 97,50 \\
\hline$<78$ & 5 & 12,50 & $\geq 78$ & 35 & 87,50 \\
\hline$<81$ & 18 & 45,00 & $\geq 81$ & 22 & 55,00 \\
\hline$<84$ & 23 & 57,50 & $\geq 84$ & 17 & 42,50 \\
\hline$<87$ & 33 & 82,50 & $\geq 87$ & 7 & 17,50 \\
\hline$<90$ & 39 & 97,50 & $\geq 90$ & 1 & 2,50 \\
\hline$<92$ & 40 & 100,00 & $\geq 92$ & 0 & 0,00 \\
\hline
\end{tabular}

Distribusi frekuensi kumulatif dan kumulatif proporsional pertama untuk melihat jumlah frekuensi kumulatif dan kedua untuk melihat frekuensi kumulatif proporsional apa sesuai dengan secara persentase yaitu seratus persen dan yang terendah adalah nol persen, kemudian daftar distribusi tersebut digunakan untuk sebagian ukuran untuk menggambarkan skor ke dalam Kurva Ogeve.

Berikut skor sikap mahasiswa reguler tahun terakhir terhadap pelaksana an pendidikan inklusi di DKI Jakarta digambarkan pada diagram histogram dan sekaligus digambarkan pula menggunakan diagram poligon frekuensi. 


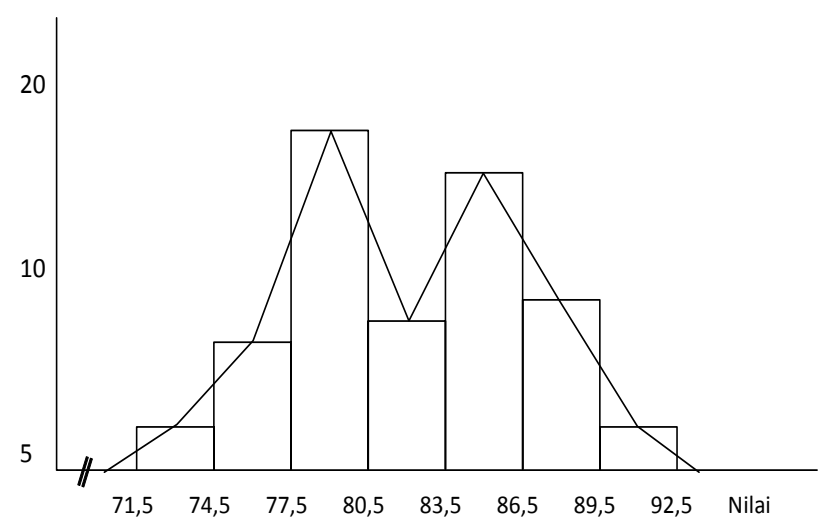

Gambar 4. Grafik Histogram dan Poligon

Skor sikap mahasiswa reguler terhadap pelaksanaan pendidikan inklusi di DKI Jakarta bahwa skor terbanyak terdapat pada batas atas 77,5 dengan 80,5 , frekuensi terbanyak kedua terletak pada batas atas 83,5 dengan 86,5 sedangkan frekuensi paling kecil terletak pada batas bawah 71,5 dan batas atas 74,5 serta batas atas 89,5 dengan 92,5.

Sedangkan grafik poligonnya tidak mengikuti bentuk kurva normal, hal ini menunjukkan data atau skor sikap mahasiswa terhadap penyelenggaraan pendidikan inklusi di DKI Jakarta belum berjalan semestinya menurut mahasiswa jurusan PLB tersebut. Dan pengetahuan mahasiswa terhadap penyelenggaraan pendidikan inklusi yang sesungguhnya belum memadai.

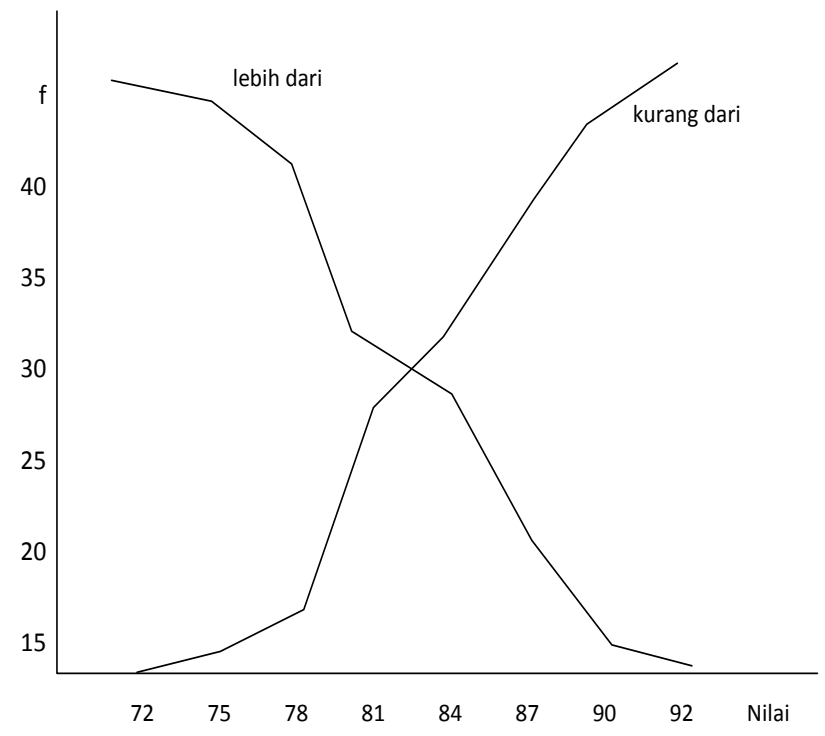

Gambar 5. Kurva Ogeve

Skor sikap mahasiswa PLB reguler terhadap penyelenggaraan pendidikan inklusi di DKI Jakarta menurut atau hasil jawaban mahasiswa masih berbedabeda dan nampak seperti menjawab instrumen sikap tersebut ada yang jumlah ragu-ragunya banyak, dan ada pula yang banyak menyatakan persetujuannya, dan sebagian yang lain lebih memadai.

\section{Pembahasan}

Sikap mahasiswa reguler tahun terakhir PLB terhadap penyelenggara-an pendidikan inklusi di DKI Jakarta berdasarkan hasil perhitungan terhadap pengujian rata-rata ideal diperoleh 54,1667, rata-rata ideal ini sebagai alat ukur tentang sikap mahasiswa terhadap penyelenggaraan pendidikan inklusi, bila skor yang diperoleh lebih dari atau sama dengan 54,1667 maka kecenderungan sikapnya adalah positif, tetapi bila skornya di bawah atau kurang dari 54,1667 kecenderungan sikapnya adalah negatif, bila sikap mahasiswa terhadap penyelenggaraan pendidikan inklusi di DKI Jakarta, maka kecenderungan mahasiswa ditandai oleh sikap untuk menjauhi, menghindari, "membenci" dan tidak menyukai obyek tersebut.

Berdasarkan skor sikap mahasiswa reguler terhadap penyelenggaraan pendidikan inklusi di DKI Jakarta ke semua sampel berjumlah 40 memiliki skor lebih dari rata-rata ideal yaitu tujuh puluh dua sampai sembilan puluh (72-90) berarti semua mahasiswa (40 orang) memiliki kecenderungan sikap positif, maka kecenderungan perilaku yang juga positif, yang ditandai oleh adanya kecenderungan tindakan untuk mendekati, menyenangi, dan mengharap kan pendidikan inklusi yang dihadapinya, dan lebih jauh mahasiswa sikap membantu, memperhatikan dan berbuat apa saja untuk memperjuangkan pendidikan inklusi.

\section{PENUTUP}

\section{Kesimpulan}

Berdasarkan hasil penelitian dan perhitungan menggunakan statistik deskriptif dan skornya menjadi rentangan 0-100, diperoleh nilai tertinggi 90, dan nilai terkecil 72 , rata-rata 81,85 , simpangan baku 4,38, variansi sebesar 19,16, diperoleh juga ukuran letak yaitu modus sebesar 79,09 dan median sebesar 80,96. Dengan simpangan baku 4,38 maka skor sikap tersebut relatif homogen.

Berdasarkan hasil perhitungan rata-rata ideal sebesar 54,1667 hal ini sebagai ukuran bahwa bila skor sikap mahasiswa lebih dari atau sama dengan rata-rata ideal berarti kecenderungan sikapnya positif dan skor sikap yang kurang dari rata-rata ideal tersebut berarti sikapnya negatif.

Pada penelitian ini, semua sampel berjumlah 40 mahasiswa, skornya di atas nilai rata-rata ideal maka kecenderungan sikapnya adalah positif, berarti kecenderungan perilakunya juga positif, yang ditandai oleh adanya kecenderungan tindakan untuk mendekati, menyenangi, dan mengharapkan 
pendidikan inklusi yang dihadapinya, dan lebih jauh siap membantu, memperhatikan, dan berbuat apa saja untuk memperjuangkan pendidikan inklusi.

\section{Saran-saran}

Berdasarkan hasil penelitian, maka saransarannya adalah sebagai berikut: (1) Untuk mahasiswa jurusan PLB FIP UNJ walaupun bersikap positif terhadap penyelenggaraan pendidikan inklusi di DKI Jakarta, mereka perlu mendapatkan penjelasan yang utuh tentang pendidikan inklusi yang sesungguhnya; (2) Untuk dosen-dosen jurusan PLB FIP UNJ supaya setiap mengajar mata kuliah apapun selalu sempatkan untuk menjelaskan pendidikan inklusi yang sesungguhnya, karena pendidikan inklusi hanya menyediakan satu layanan pendidikan yaitu anak berkebutuhan khusus belajar bersama anak normal dan diajar oleh guru kelas; dan (3) untuk para peneliti supaya dapat membuat penelitian di bidang pendidikan inklusi seperti mengetahui pemahaman guru-guru di pendidikan inklusi terhadap kebutuhan pendidikan ABK.

\section{DAFTAR PUSTAKA}

Arum, W.S. A. 2005. PerspektifPendidikan Luar Biasa dan Implikasinya Bagi Penyiapan Tenaga Kependidikan. Jakarta: Depdiknas, Dirjen Dikti

Azwar, S. (2005). Sikap Manusia, Teori dan Pengukurannya (Edisi Kedua). Yogyakarta: Pustaka Pelajar Offset.

Chaolin, D.P. (1993) Kamus Lengkap Psikologi. Jakarta: PT Raja Grafindo Persada.
Elkins, Dan J. (Ed). (1994). Educating Children with Special Needs (2nd ed). Australia: Prentice Hall.

Direktorat PLB. (2004). Mengenal Pendidikan Terpadu Jakarta: Kementrian Pendidikan Nasional. Mar'at (1982). Sikap Manusia Perubahan serta Pengukurannya. Jakarta: Gallia Indonesia

Direktorat PLB. (2004). Pengembangan Kurikulum dalam Pendidikan Inklusi. hh. 7-8, 2004 (http://www. ditplb.or.id/ profile.php?id=42)

Siti Nuraini P, dkk. (2003). Kajian Teoritik Tentang Pendidikan Inklusi bagi Siswa dengan Ketidakmampuan Intelektual (Tunagrahita). Jakarta: LEMLIT UNJ.

Soleh, D. A. (2003). Hubungan Antara Pengetahuan Tentang Konstruksi Tes dan Sikap Terhadap Profesi Guru dengan Validitas Tes Buatan Mahasiswa Program Tatap Muka (PTM) PGSD UNJ (Makalah Kualifikasi). Jakarta: Program Pascasarjana UNJ.

Tri Dayakisni \& Hudaniah. (2003). Psikologi Sosial. Malang: UMM Press.

Wortmand, C.N., Loftus E.F., dan Knopt, A.A. (1985). Psychology, 2nd Ed., New York.

Winkel, WS. (1991). Psikologi Pengajaran. Jakarta: Grasindo.

\section{KETERANGAN PENULIS}

Nirsantono Hasnul, saat ini bertugas sebagai dosen tetap di jurusan Pendidikan Luar Biasa Universitas Negeri Jakarta. 